\title{
Non-Peptide Small Molecule Regulators of Lymphangiogenesis
}

\author{
Changge Fang, Ph.D.,' Marta Aparicio Miguel, B.Sc., ${ }^{1,2}$ Ingalill Avis, R.N., \\ Alfredo Martinez, Ph.D., ${ }^{3}$ Enrique Zudaire, Ph.D., and Frank Cuttitta, Ph.D.
}

\begin{abstract}
Adrenomedullin (AM) and gastrin releasing peptide (GRP) are neuroendocrine peptides that have been previously implicated as regulators of angiogenesis and lymphangiogenesis. Using an immortalized human dermal microvascular lymphatic endothelial cell line stably transfected with red fluorescent protein (LEC/RFP), we demonstrate the ability of AM and GRP to augment tube formation complexity of this target cell in a dosedependent manner. Maximum tube density was initiated at $1 \mathrm{n} M$ for both peptides, and as concentrations exceeded $10 \mathrm{nM}$ a decrease in tube formation was noted, hence following a classic rise/fall biological response curve. In addition, we show that appropriate small molecule mimetics to neutralizing monoclonal antibodies of AM or GRP, at $1 \mu \mathrm{M}$ concentration, can function to either inhibit (antagonist) or enhance (super agonist) peptideinduced tube formation of LEC/RFP. Our small molecule reagents by themselves have no activity, but in the presence of their respective peptides can mediate a positive or negative response, hence the super agonist designation. These compounds represent new regulatory drugs of the lymphatic system with possible patient application in the clinical management of edema and metastatic disease.
\end{abstract}

\section{Introduction}

$\mathbf{H}$ OMEOSTASIS OF THE LYMPHATIC SYSTEM is critical for controlling the immune response and maintaining fluid balance in the body. ${ }^{1}$ Anomalies in lymphatic integrity can have diverse detrimental effects on patients ranging from generalized edema to the metastatic spread of cancer. ${ }^{2}$ Understanding the growth regulatory mechanisms underlying lymphangiogenesis allows investigators the opportunity to develop drugs that either enhance or suppress this tubular network process, contingent on the disease state confronted. Within the past decade, major strives in lymphatic research have identified specialized markers that distinguish blood vessel endothelial cells from that of lymphatic components, including LYVE-1, podoplanin, and Prox1, among others. ${ }^{3-7}$ The pioneering efforts of Kari Alitalo (University of Helsinki, Finland) and co-workers have revolutionized our working knowledge of lymphatic endothelial cell proliferative mechanisms and embryonic to adult transition events. ${ }^{8-15}$ Major advances have been generated in in vitro and in vivo lymphangiogenic assay development, allowing investigators the possibility to rapidly evaluate growth regulatory drugs for potential clinical use. ${ }^{16,17}$ Finally, SV40 large T antigen or telomerase immortalized blood vessel and lymphatic endothelial cell lines are now becoming available, thus circumventing the short-term culture characteristics of primary endothelial cells and making assay standardization a reachable possibility in the field. ${ }^{18-20}$

The identification of strategic drugs that regulate the proliferative components of lymphangiogenesis has been a challenge for clinical investigators over the past several decades. Recent findings have revealed that certain neuropeptides can modulate endothelial cell growth events and may offer rational targets for drug development. Two such entities, adrenomedullin (AM) and gastrin-releasing peptide (GRP), both amidated peptides, have been found to be mitogenic for endothelial cells. ${ }^{21-26}$ The only known carboxy-terminal post-translational modification of proteins that consistently tracks with bioactivity is amidation, a process that requires a unique amino acid recognition motif in the prohormone molecule which in turn encodes for a series of consecutive enzymatic steps that ultimately leads to peptide amide formation. ${ }^{27-29}$ Figure 1 summarizes the amino acid (AA) motif encoded in the prohormones of AM or GRP that dictates

${ }^{1} \mathrm{NCI}$ Angiogenesis Core Facility, National Cancer Institute, Center for Cancer Research, Radiation Oncology Branch, Advanced Technology Center, Bethesda, Maryland.

2Department of Molecular Biology, Autonomous University of Madrid, Madrid, Spain.

${ }^{3}$ Oncology Area, Center for Biomedical Research of La Rioja, Logroño, Spain. 
the amidation process to take place via a series of enzymatic events (trypsin-like cleavage between Arg-Ser or Lys-Ser, several rounds of carboxypeptidase hydrolysis to remove the basic AA, processing of the glycine-extended intermediate compounds [-GlyTyr-Gly or -Leu-Met-Gly] by the peptidylalpha-amidating monooxygenase complex, and finally terminating in amidated AM or GRP) as shown. ${ }^{27-29}$ The free acid and glycine-extended intermediates of AM or GRP are several orders of magnitude less potent than the corresponding peptide amide when tested in a variety of biological systems. ${ }^{27-29}$ Drugs that target either the carboxy-terminal amide region of AM and GRP or the amide conformational recognition site on their cognate receptors will effectively block the peptide's biological activity by steric interference with ligand/receptor binding. ${ }^{23,30,31} \mathrm{AM}$ has now been shown to be an important stimulator of lymphatic vascular development during embryogenesis and an ameliorator of lymphedema. ${ }^{32,33}$ Over two decades ago GRP was found to be a peptide product of lymphatic vessels that regulated the function of this network system in an autocrine/paracrine manner. ${ }^{34}$ We have previously reported on the development of monoclonal antibodies that target the carboxy-terminal amide of either AM or GRP, denoted as MoAb-G6 and MoAb2A11, respectively. ${ }^{30,31}$ MoAb-G6 did not cross react with GRP nor did MoAb-2A11 bind AM. These antibodies were

\section{Adrenomedullin (AM)}

52AA, Autocrine/Paracrine Growth Factor, Ubiquitous

Expression, Tyrosine Amide

PreproAM - 185AA

Amidation Motif - proAM145-153
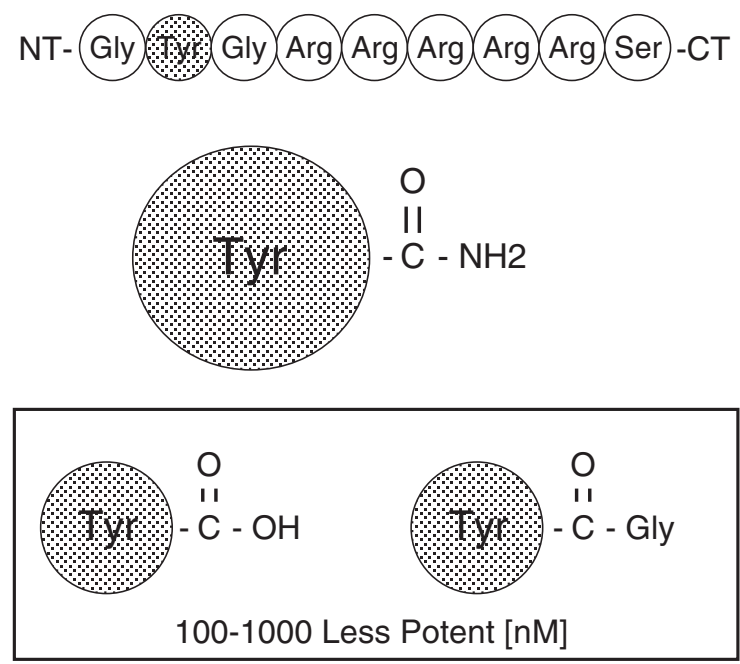

shown to form immune complexes with their respective peptide immunogens and to block the biological activity of these peptides in a variety of in vitro and in vivo assay systems. ${ }^{30,31}$ As illustrated in Figure 2, we have recently utilized these neutralizing monoclonal antibodies to establish a high throughput screening strategy for identifying small molecule mimetics to these immune reagents. ${ }^{35}$ These small molecule compounds (Fig. 3 ) were shown to function as augmenters or suppressors of AM or GRP bioactivity. ${ }^{26,35}$ In the following text, we will demonstrate AM and GRP as inducers of lymphangiogenesis and utilize our small molecule reagents to modulate (antagonist and super agonist) the biological activity of these peptide amides on lymphatic endothelial cells.

\section{Materials and Methods}

\section{Cell line}

A telomerase immortalized human dermal microvascular lymphatic endothelial cell line (hTERT-HDLEC) was acquired through a NIH Material Transfer Agreement with Dr. Michael Pepper (Department of Morphology, University Medical Center, Lausanne, Switzerland). ${ }^{19}$ hTERT-HDLEC were stably transfected with pDsRed-C1 (Clontech Laboratories, Inc., Mountain View, CA, USA) using standard AMAXA (Lonza Walkersville, Inc., Walkersville, MD, USA) protocols, G418

\section{Gastrin Releasing Peptide (GRP)}

27 AA, Autocrine/Paracrine Growth Factor, Ubiquitous

Expression, Methionine Amide

PreproGRP - 148AA

Amidation Motif - proGRP49-54
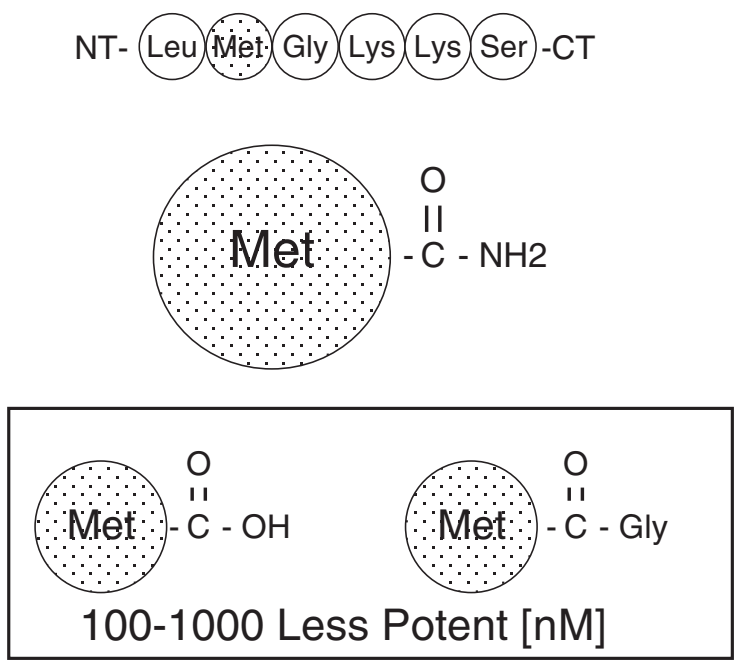

FIG. 1. Carboxy terminal amidation of peptides: a hallmark of peptide biological activity. ${ }^{27-29}$ Two such amidated peptides, $\mathrm{AM}$ and GRP, are proven inducers of neovascularization and have recently been implicated in lymphangiogenesis. ${ }^{21-26,} 32-34$ A distinct amino acid (AA) motif within the prohormone signals for amidation to take place and consists of a target AA to be amidated (any AA), followed by glycine (only known amide donor AA), followed by a series of basic AAs (arginine or lysine). An initial trypsin-like cleavage event releases the amidation motif from the prohormone, followed by carboxypeptidase processing, giving rise to a glycine-extended intermediate product. This intermediate then serves as the substrate for a unique series of enzyme complexes known as peptitdyl-glycine-amidating monoxygenase that ultimately generates the amide of glycine's penultimate neighbor AA. The prohormone amidation motifs for AM (a tyrosine amide) and GRP (a methionine amide) are shown. The glycine intermediate or free-acid derivatives of both AM and GRP are 100 to 1000 time less potent on a molar basis than their respective amide counter-part depending on the biological assay used (boxed structures). 
ID Neutralizing MoAb

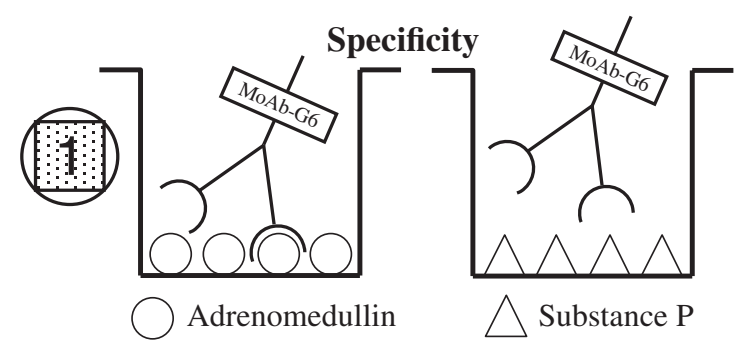

$\underline{\text { ID Small Molecule Mimetic }}$

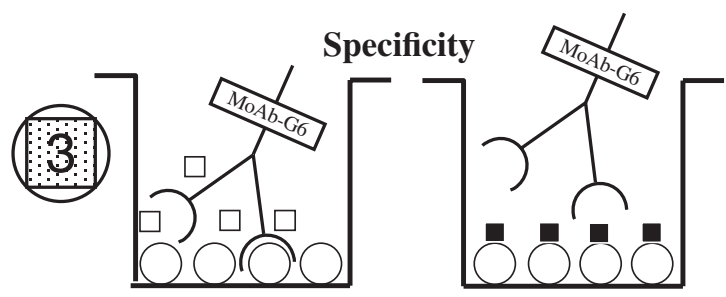

$\underline{\text { In Vitro Bioassay Application }}$
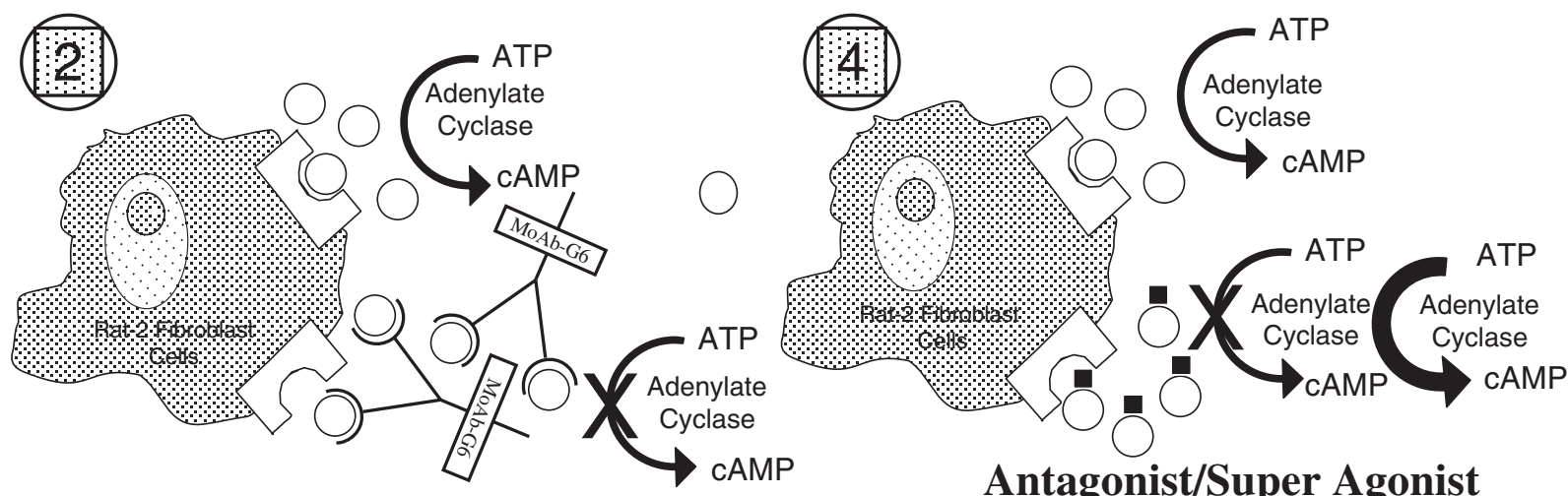

Antagonist/Super Agonist

FIG. 2. Small molecule drug screening approach. Screening strategy design for high throughput analysis using a 96-well microtiter plate format and based on prior NCI technology. ${ }^{35}$ Section No. 1 indicates the initial testing of hybridoma products for ligand binding specificity. Here AM (a tyrosine amide) was used as the immunogen and the solid phased target peptide, while substance P (amethionine amide) was used as a negative control peptide. ${ }^{31}$ Section No. 2 depicts the bioassay used to identify preselected anti-AM monoclonal antibodies $(\mathrm{MoAb})$ as peptide neutralizing reagents. AM induces Rat-2 fibroblast cells to concert ATP > cAMP and MoAb-G6, identified in Section No. 1, blocks that event. Section No. 3. A secondary binding assay was established involving MoAb-G6/AM interaction and the NCI/Developmental Therapeutics Program (DTP) diversity set of 2000 small molecules family members (representing 140,000 compounds) were screened for their ability to inhibit ligand/antibody complex formation. Section No. 4. Candidate compounds making it through this initial screening were then evaluated in the Rat-2 fibroblast assay for their effects on AM-induced cAMP production. As indicated, small molecule AM antagonist and super agonist compounds were found using this collective screening strategy. ${ }^{35}$ An identical collective screening approach was used to identify small molecule regulators of GRP bioactivity with MoAb-2A11 serving as the neutralizing anti-GRP antibody. ${ }^{30,35}$

(Invitrogen, Life Technologies Corporation, Carlsbad, CA, USA) selected, and FACS sorted for highest percent of fluorescent cells and highest intensity of fluorescence. The resulting cell population was denoted as LEC/RFP. LEC/RFP were maintained in EMB2 complete medium (Lonza).

\section{Small molecule drugs}

Small molecules NSC 16311 (AM antagonist), NSC 697169 (AM super agonist), NSC 77427 (GRP antagonist), and NSC 372874 (GRP super agonist) have been previously described. ${ }^{35}$

\section{Tube formation}

LEC/RFP were grown to $60 \%$ confluence in EMB2 complete medium (Lonza) and re-fed $24 \mathrm{~h}$ before use in the tube formation assay. $50 \mu \mathrm{l}$ of chilled geltrex (Invitrogen) was added to each well of a pre-chilled 96-well microtiter tissue culture plate (Costar, Corning Inc., Corning, NY, USA) and transferred to a $37^{\circ} \mathrm{C} / 5 \% \mathrm{CO} 2$ incubator until solidified (approximately $45 \mathrm{~min}$ ). Cells were trypsinized, washed three times in PBS, and resuspended in EBM $2+0.5 \%$ fetal bovine serum (FBS) at a final concentration of 380,000 cells $/ \mathrm{ml}$. AM and GRP were evaluated for the ability to induce LEC/RFP tube formation over a nanomolar dose range covering several orders of magnitude $(0.01 \mathrm{nM}, 0.1 \mathrm{n} M, 1.0 \mathrm{n} M, 10 \mathrm{n} M$, and $100 \mathrm{nM})$. Small molecule regulators of AM or GRP were used at $1 \mu \mathrm{M}$. $50 \mu \mathrm{l}$ LEC/RFP cell suspensions (19,000 cells) under specified test conditions were added in quadruplicate to the microtiter plate and incubated at $37^{\circ} \mathrm{C} / 5 \% \mathrm{CO} 2$ for $3.5 \mathrm{~h}$ before assessing the complexity of tubes formed by fluorescence microscopy.

\section{Results}

\section{AM- and GRP-induced dose response} on tube formation

Figure 4 demonstrates AM- and GRP-mediated tube formation capabilities when tested over a dose range of $0.01 \mathrm{nM}$ to $100 \mathrm{nM}$ on LEC/RFP target cells. A classic rise/fall (biphasic) dose response curve was generated for both peptides 


\section{AM Antagonist NSC 16311}

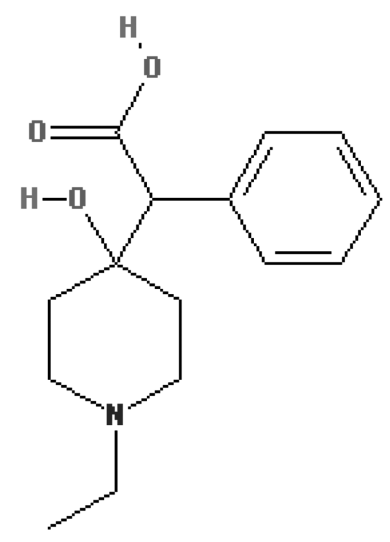

\section{AM Super Agonist NSC 697169}

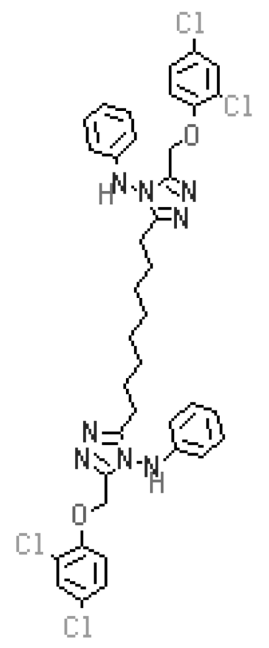

\section{GRP Antagonist NSC 77427}

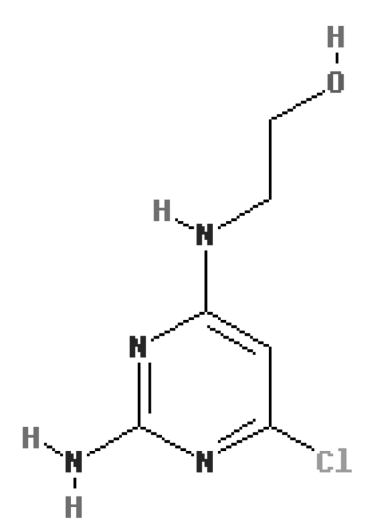

\section{GRP Super Agonist NSC 372874}

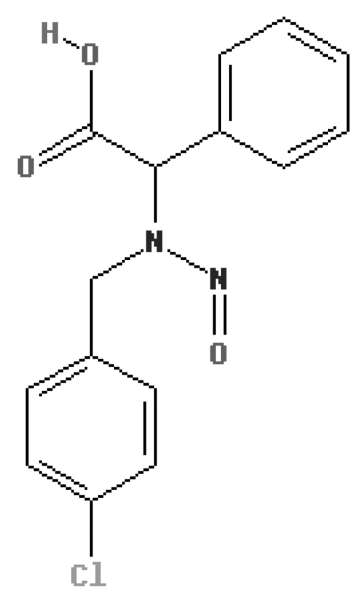

FIG. 3. Chemical structure of small molecule AM/GRP antagonists and super agonists. Average formula weight (FW) approximately 300 daltons (NSC 697169 exception with FW 781).

(36), maximizing at $1 \mathrm{nM}$ and dropping as concentrations exceed $10 \mathrm{nM}$. Although AM promotes a steeper dose response curve than GRP, the latter peptide appears to be more potent on a molar basis given the augmentation in network assembly noted at the $0.01 \mathrm{n} M$ dose when compared to an equivalent AM concentration. In addition, several FBS concentrations $(0,0.5 \%$ and $5 \%)$ were evaluated to determine the ideal serum supplementation level to incorporate into the assay for maximum sensitivity of results. $0.5 \%$ FBS was chosen for all follow- up tube formation assays in these series to overcome zero serum threshhold but still offer a large dynamic range for peptide induced responses to be observed.

\section{Small molecule regulators of AM- or GRP-induced tube formation}

Figure 5 summarizes the LEC/RFP tube formation results obtained by varying the FBS concentration over a dose range

of zero, $0.5 \%$ and $5 \%$, thus serving as a comparison standard for peptide-induced network complexity with or without small molecule regulators. For all follow-up studies, a $0.5 \%$ serum supplementation was used. Peptides were evaluated at $0.1 \mathrm{nM}$, a concentration below their maximum stimulatory dose to enhance the sensitivity of the assay. Small molecules were initially tested at $1 \mu M$ concentration based on our prior working experience with these drugs for in vitro assay systems, assuring us the possibility of seeing a valid response. ${ }^{26,35} \mathrm{AM}$ and GRP at $0.1 \mathrm{n} M$ augmented the resulting network complexity of LEC/RFP over that seen for $0.5 \%$ FBS in the absence of peptide. In addition, the AM antagonist (NSC 16311) and the GRP antagonist (NSC 77427) markedly suppressed peptide induced tube formation. Conversely, the AM super agonist (NSC 697169) enhanced network complexity while the GRP super agonist (NSC 372874) appeared to do little to elevate the response over that of the peptide alone, possibly reflecting the muted biphasic response curve of this peptide.

\section{Discussion}

Here we report on the use of these small molecule compounds to enhance or suppress AM- and GRP-induced lymphatic endothelial cell tube formation. Tube formation, although not involving a proliferative component, does reflect key aspects of lymphangiogenesis, namely cell migration and organizational establishment of a network infrastructure. Figure 4 demonstrates the potential for AM and GRP to drive these aspects of lymphangiogenesis in a dose-dependent manner. Subnanomolar concentrations of either AM or GRP can mediate lymphatic endothelial cell tube formation, thus implicating a possible physiological role for these peptides in lymphatic network development in vivo. This supposition has been substantiated by published findings from other laboratories. ${ }^{32,33}$ A biphasic response curve was generated over the peptide dose range assessed. This observed rise/fall response tends to be indicative of either receptor dimerization or the presence of high/low affinity receptors. ${ }^{37,38}$ When receptor dimerization is involved, low peptide concentrations maximize receptor cross-linking, augmenting the response whereas high peptide level drive monomer formation muting the peptide induced effect. ${ }^{37}$ Alternatively, when different receptor affinities underlie the biphasic response, low peptide concentrations preferentially triggers the high affinity receptor while high peptide levels activate the low affinity receptor. ${ }^{38}$ Interestingly, high/low affinity receptors are known to exist for both AM and GRP. ${ }^{39,40}$

In Figure 5, when applying our small molecule regulators to AM or GRP induced lymphatic network assembly in vitro, we clearly see suppressive effects with the AM antagonist (NSC 16311) and GRP antagonist (NSC 77427) used at a $1 \mu \mathrm{M}$ concentration.

Conversely, the AM super agonist (NSC 697169) augments tube formation while the GRP super agonist (NSC 372874) does not show an enhancement of vascular complexity over that seen by GRP alone. This NSC 372874 effect may be a reflection of the shallow dose response curve observed for GRP-mediated tube formation or possibly be indicative of suppressive effects observed at the higher peptide concentrations of the biphasic response. Evaluating GRP at a diminished concentration $(0.01 \mathrm{nM}$ or lower $)+$ NSC 372874 

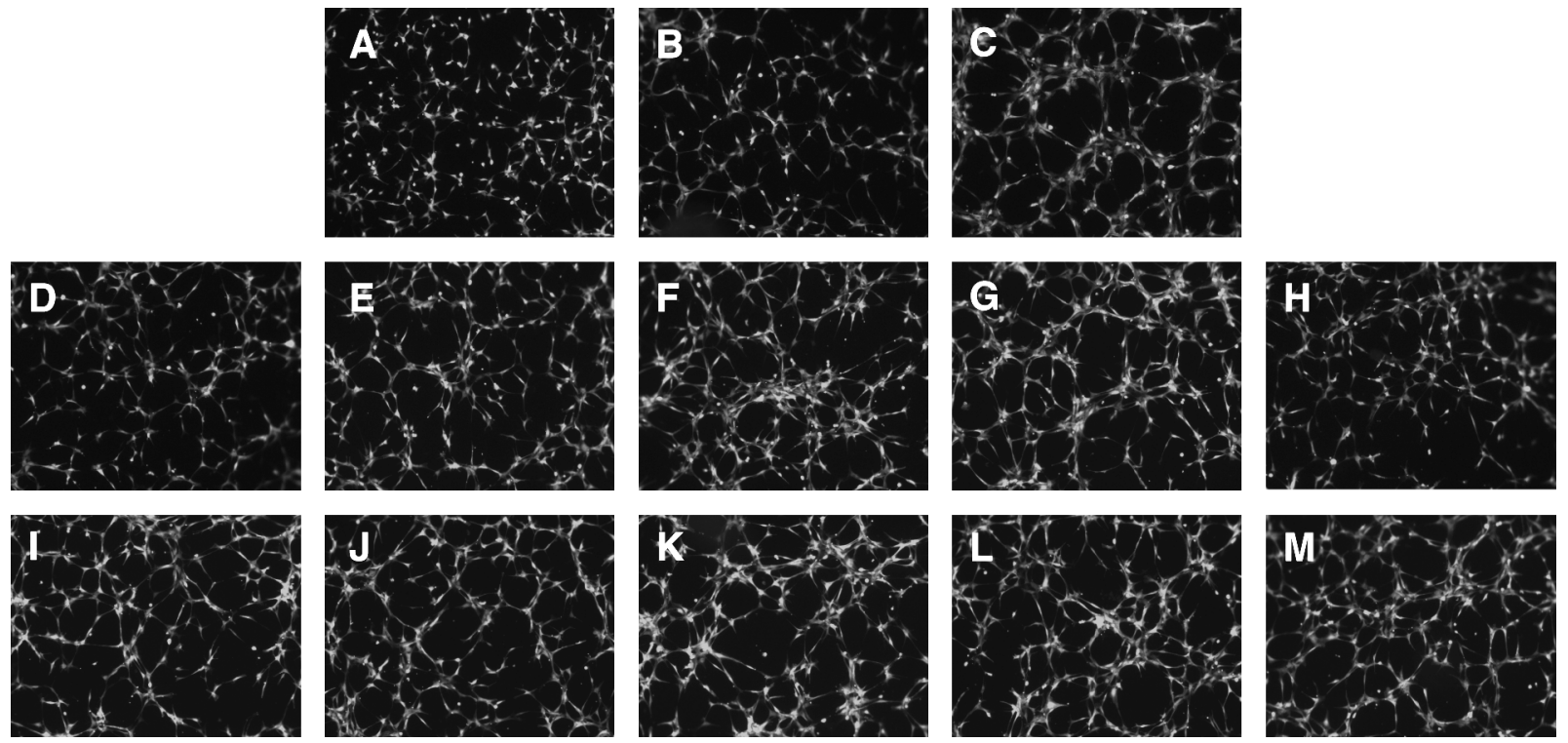

FIG. 4. In vitro tube formation assay. Telomerase immortalized human dermal lymphatic endothelial cells stably transfected with RFP (LEC/RFP) were utilized in this 96-well analysis, seeding density of 19,000 cells/well, and evaluated after $3.5 \mathrm{~h}$ incubation at $37{ }^{\circ} \mathrm{C} / 5 \% \mathrm{CO} 2$. A, B, and $\mathbf{C}$ represent serum induced tube formation at $0 \%, 0.5 \%$, and $5 \%$ FBS, respectively. A mid-range of $0.5 \%$ FBS supplementation was chosen for all follow-up studies related to peptide-induced tube formation. D, E, F, G, and $\mathbf{H}$ represent resulting tubes observed when stimulated with $\mathrm{AM}$ at $0.01 \mathrm{n} M, 0.1 \mathrm{n} M, 1.0 \mathrm{n} M, 10 \mathrm{nM}$, and $100 \mathrm{n} M$ concentration. I, J, K, L, and $\mathbf{M}$ are the GRP-induced tubes formed when tested at a peptide concentration of $0.01 \mathrm{n} M, 0.1 \mathrm{n} M$, $1.0 \mathrm{n} M, 10 \mathrm{n} M$, and $100 \mathrm{n} M$. Note that both peptides induce a biphasic dose response curve (AM having a steeper response curve than GRP) with maximum tube formation generated at a peptide concentration of $1.0 \mathrm{n} M$.

may improve the visualization of a super agonist effect. Interestingly, small molecules we defined as super agonists by themselves have no effect; they only induce their stimulatory influence in the presence of their respective peptides. In addition, the observed super agonist's enhancement of peptide potency is not dependent on increasing ligand/receptor affinity but potently involves the masking of enzymatic degradation sites on $\mathrm{AM} / \mathrm{GRP}$ thus extending the biological half-life of the peptide. ${ }^{41}$

Recent evidence has suggested that both AM and GRP can function as cell mitogens either directly through designated receptor binding or indirectly by transactivation of an unrelated secondary receptor system. ${ }^{24,42}$ When AM binds to its respective cognate receptor AM1 (CRLR/RAMP2) on endothelial cells, a transactivation of the VEGFR2 (Flk1/KDR) takes place, triggering the VEGF-A pathway independent of the VEGF-A ligand and resulting in endothelial cell proliferation. ${ }^{24}$ Similar transactivation effects have been identified for GRP interaction with the GRP receptor (GRPR), stimulating the epidermal growth factor receptor (EGF) independent of ligand and augmenting the growth of human squamous cell carcinomas. ${ }^{42}$ Given that AM and GRP can influence biological events via transactivation of secondary receptor systems, our small molecule regulators may also be having both direct and indirect effects on peptide-mediated lymphangiogenesis. This becomes particularly important considering that AM and GRP are products of squamous cell carcinoma and this tumor type has recently been implicated in a VEGF-C/Flt4 autocrine loop mechanism regulating tumor growth with paracrine modulation of tumor-associate lymphangiogenesis. ${ }^{42-44}$ Hence this squamous cell carcinoma tumor model may be an ideal system to test the possible indirect influence of AM or
GRP on tumor-associated lymphangiogenesis and to determine how our small molecule regulators may influence these potential interactions.

Critically important in moving the lymphatic field forward is the development of new assay systems representing in vitro or in vivo approaches to lymphangiogenesis. Several new discoveries have exemplified these types of investigative advancements incorporating three-dimensional designs of lymphatic endothelial cells in gel matrices to mimic physiological conditions or identifying anatomical sites in host animals readily assessable for monitoring inducible lymphangiogenesis. ${ }^{16,17,45}$ Such test systems offer investigators the opportunity to identify novel drugs that modulate lymphatic network complexity or uncover naturally occurring mechanisms regulating lymphangiogenesis as was recently seen with the discovery of a soluble alternatively splice variant of VEGFR-2 (sVegfr-2) that inhibits lymphatic hyperplasia but not angiogenesis. ${ }^{46,47}$ It should be noted that our high throughput screening strategy for identifying small molecule mimetics to neutralizing monoclonal antibodies can also be applied to ligand/receptor interactions, and the VEGF-C/ sVegfr-2 model would be an interesting system to examine for antagonist/agonist small molecule regulators.

In conclusion, we have demonstrated the ability of AM and GRP to mediate LEC/RFP tube formation in a dosedependent manner. Subnanomolar concentrations of both peptides clearly augment lymphatic vessel density over that observed in the absence of peptide, hence implicating a possible physiological role for these peptides in lymphangiogenesis in vivo. This hypothesis has in fact been validated by published studies from other laboratories. ${ }^{32-34}$ We have also shown that small molecule mimetics to neutralizing 

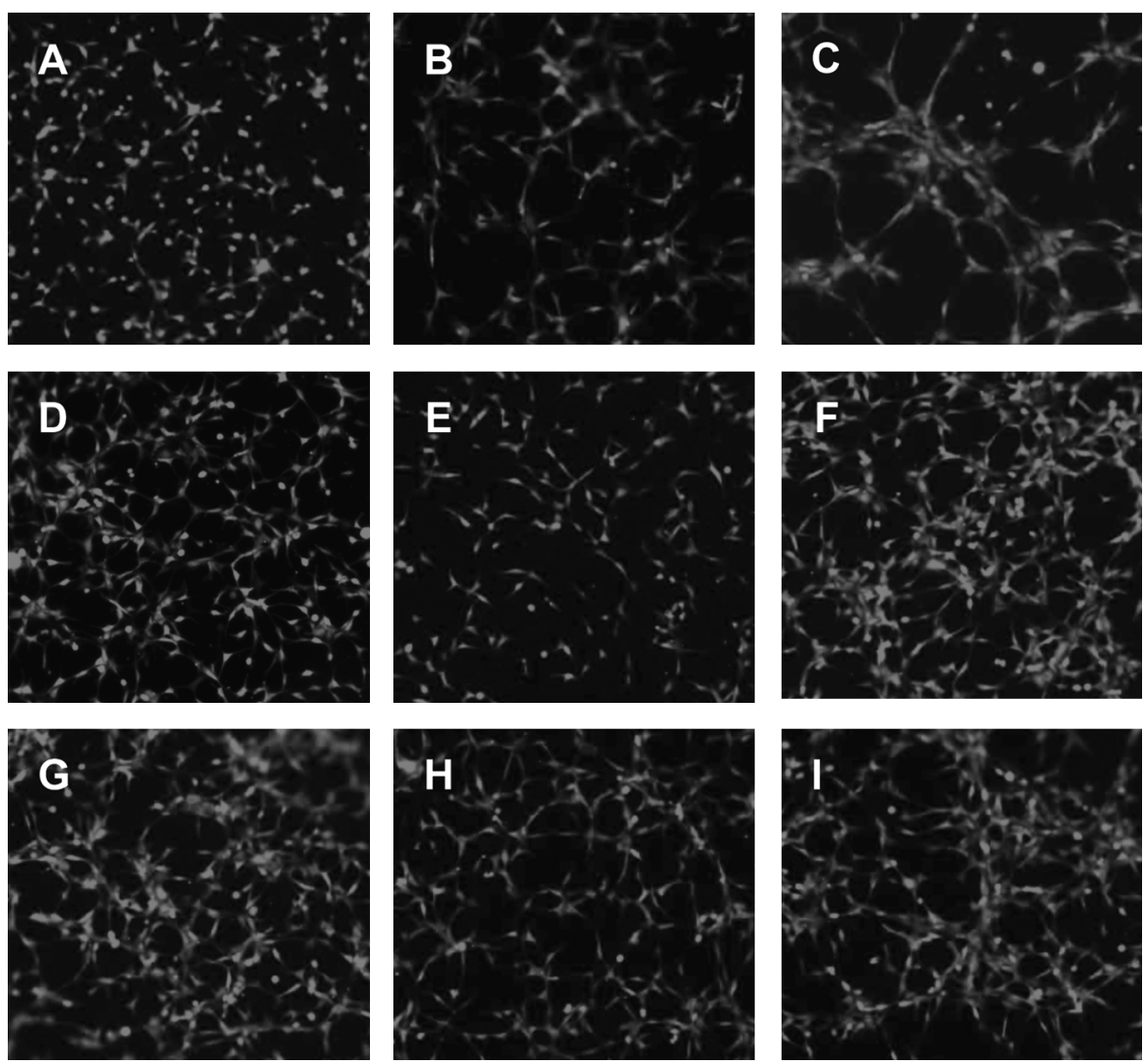

FIG. 5. Testing small molecule regulators of AM and GRP in the tube formation assay. An identical assay as described in Figure 4 was established to evaluate the ability of small molecule antagonists and agonists to regulate peptide-induced tube formation with LEC/RFP target cells. A, B, and C represent tube formation observed in the presence of $0 \%, 0.5 \%$, and $5 \%$ FBS supplementation, respectively. $\mathbf{D}, \mathbf{E}$, and $\mathbf{F}$ are representative examples of the lymphatic tube formation generated in the presence of $0.5 \%$ FBS $+0.1 \mathrm{n} M$ AM, followed by the addition of either $1 \mu M$ AM antagonist (NSC 16311) or $1 \mu M$ AM super agonist (NSC 697169). G, H, and I are representative responses with $0.5 \%$ FBS $+0.1 \mathrm{nM}$ GRP followed by the addition of either $1 \mu M$ GRP antagonist (NSC 77427) or $1 \mu M$ GRP super agonist (NSC 372874).

monoclonal antibodies for AM/GRP can regulate peptideinduced LEC/RFP tube formation. The AM antagonist (NSC 16311) and GRP antagonist (NSC 77427), at a $1 \mu \mathrm{M}$ dose, suppressed peptide mediated enhancement of LEC/RFP vessel density. It would be interesting to evaluate these reagents for their anti-metastatic effects on murine models of breast or lung cancer, given the known lymphatic dissemination events underlying the spread of these tumors to distal anatomical sites and the evolutionary conservation of AM/GRP among mammalian species. In addition, our small molecule super agonist for AM (NSC 697169) was shown to enhance peptideinduced LEC/RFP tube formation while a parallel reagent for GRP (NSC 372874) was not effective in stimulating network density. This negative result may be caused by a variety of influencing factors previously discussed in this section, and the drug should not be discarded without further testing, especially since it was proven to be an enhancer of GRP activity in other biological systems. Given the established mouse model used to validate AM's influence on adult lymphangiogenesis and lymphedema, ${ }^{32,33}$ it would be interesting to see if our small molecule regulators of AM bioactivity can augment or suppress AM-mediated lymphatic events in this in vivo system. Small molecule compounds represent an ideal drug format because of their extremely diffusible size (usually $<400$ daltons), resistance to proteolytic degradation in the circulation, ease of generating structural modifications via combinatorial chemistry, and low GMP cost for certified FDA therapeutic production compared to neutralizing monoclonal antibodies. To summarize, we have identified several small molecule compounds that effectively modulated the stimulatory effects of AM/GRP on lymphangiogenesis, thus having potential clinical use in combating lymphatic disorders.

\section{Acknowledgments}

This research was supported by the intramural research program of the NCI, NIH, DHSS under Project No. BC01096401 CCRO. NCI small molecule intellectual property is covered under U.S. patent application 10/57 1,012. The content of this publication does not necessarily reflect the views or policies of the DHSS nor does mention of trade names, commercial products, or organizations imply endorsement by the U.S. Government.

\section{Disclosure Statement}

The authors of this article, Changge Fang, Marta Aparicio Miguel, Ingalill Avis, Alfredo Martinez, Enrique Zudaire, and Frank Cuttitta, have no conflicts of interest or financial ties to disclose. 


\section{References}

1. Olszewski W. The lymphatic system in body homeostasis: Physiological conditions. Lymphat Res Biol 2003;1:11-21.

2. Butler MG, Isogai S, Weinstein BM. Lymphatic development. Birth Defects Res 2009;87:222-231.

3. Rocha SF, Adams RH. Molecular differentiation and specialization of vascular beds. Angiogenesis 2009;12:139-147.

4. Banerji S, Ni J, Wang SX, Clasper S, Su J, Tammi R, Jones M, Jackson DG. LYVE-1, a new homologue of the CD44 glycoprotein, is a lymph-specific receptor for hyaluronan. J Cell Biol 1999;144:789-801.

5. Wigle JT, Oliver G. Prox1 function is required for the development of the murine lymphatic system. Cell 1999;98: 769-778.

6. Wigle JT, Harvey N, Detmar M, Lagutina I, Grosveld G, Gunn MD, Jackson DG, Oliver G. An essential role for Prox1 in the induction of the lymphatic endothelial cell phenotype. EMBO J 2002;21:1505-1513.

7. Breiteneder-Geleff S, Soleiman A, Kowalski H, Horvat R, Amann G, Kriehuber E, Diem K, Weninger W, Tschachler E, Alitalo K, Kerjaschki D. Angiosarcomas express mixed endothelial phenotype of blood and lymphatic capillaries: podoplanin as a specific marker for lymphatic endothelium. Am J Pathol 1999;154:385-394.

8. Joukov V, Pajusola K, Kaipainen A, Chilov D, Lahtinen I, Kukk E, Saksela O, Kalkkinen N, Alitalo K. A novel vascular endothelial growth factor, VEGF-C, is a ligand for the Flt4 (VEGFR-3) and KDR (VEGFR-2) receptor tyrosine kinases. EMBO J 1996;15:290-298.

9. Jeltsch M, Kaipainen A, Joukov V, Meng X, Lakso M, Rauvala H, Swartz M, Fukumura D, Jain RK, Alitalo K. Hyperplasia of lymphatic vessels in VEGF-C transgenic mice. Science 1997;276:1423-1425.

10. Karkkainen MJ, Haiko P, Sainio K, Partanen J, Taipale J, Petrova TV, Jeltsch M, Jackson DG, Talikka M, Rauvala H, Betsholtz C, Alitalo K. Vascular endothelial growth factor C is required for sprouting of the first lymphatic vessels from embryonic veins. Nat Immunol 2004;5:74-80.

11. Lohela M, Heloterä $H$, Haiko P, Dumont DJ, Alitalo K. Transgenic induction of vascular endothelial growth factor- $C$ is strongly angiogenic in mouse embryos but leads to persistent lymphatic hyperplasia in adult tissue. Am J Pathol 2008;173:1891-1901.

12. Joukov V, Sorsa T, Kumar V, Jeltsch M, Claesson-Welsh L, Cao Y, Saksela O, Kalkkinen N, Alitalo K. Proteolytic processing regulates receptor specificity and activity of VEGF-C. EMBO J 1997;16:3898-3911.

13. Ristimäki A, Narko K, Enholm B, Joukov V, Alitalo K. Proinflammatory cytokines regulate expression of the lymphatic endothelial mitogen vascular endothelial growth factor-C. J Biol Chem 1998:273:8413-8418.

14. Laakkonen P, Waltari M, Holopainen T, Takahashi T, Pytowski B, Steiner P, Hicklin D, Persaud K, Tonra JR, Witte L, Alitalo K. Vascular endothelial growth factor receptor 3 is involved in tumor angiogenesis and growth. Cancer Res 2007;67:593-599.

15. Cao Y, Linden P, Farnebo J, Cao R, Eriksson A, Kumar V, Qi $\mathrm{JH}$, Claesson-Welsh L, Alitalo K. Vascular endothelial growth factor $\mathrm{C}$ induces angiogenesis in vivo. Proc Natl Acad Sci USA 1998;95:14389-14394.

16. Bruyère $F$, Melen-Lamalle $L$, Blacher $S$, Roland $G$, Thiry $M$, Moons L, Frankenne F, Carmeliet P, Alitalo K, Libert C, Sleeman JP, Foidart J-M, Noël A. Modeling lymphangio- genesis in a three-dimensional culture system. Nat Methods 2008;5:431-437.

17. Bruyère F, Noël A. Lymphangiogenesis: In vitro and in vivo models. FASEB J, published online, September 2009.

18. Ades EW, Candal FJ, Swerlick RA, George VG, Summers S, Bosse DC, Lawley TJ. HMEC- 1: Establishment of an immortalized human microvascular endothelial cell line. J Invest Dermatol 1992;99:683-390.

19. Nisato RE, Harrison JA, Buser R, Orci L, Rinsch C, Montesano R, Dupraz P, Pepper MS. Generation and characterization of telomerase-transfected human lymphatic endothelial cells with an extended life span. Am J Pathol 2004;165:11-24.

20. Schoppmann SF, Soleiman A, Kalt R, Okubo Y, Benisch C, Nagavarapu U, Herron GS, Geleff S. Telomerase-immortalized lymphatic and blood vessel endothelial cells are functionally stable and retain their lineage specificity. Microcirculation 2004:11:261-269.

21. Nikitenko LL, MacKenzie IZ, Rees MCP, Bicknell R. Adrenomedullin is an autocrine regulator of endothelial growth in human endothelium. Mol Hum Reprod 2000;6:811-819.

22. Martínez A, Vos M, Guédez L, Kaur G, Chen Z, Garayoa M, Pío R, Moody T, Stetler-Stevenson W, Kleinman HK, Cuttitta F. The effects of adrenomedullin overexpression in breast tumor cells. J Natl Cancer Inst 2002;94:1226-1237.

23. Zudaire E, Martínez A, Garayoa M, Pío R, Kaur G, Woolhiser MR, Metcalfe DD, Hook WA, Siraganian RP, Guise TA, Chirgwin JM, Cuttitta F. Adrenomedullin is a cross-talk molecule that regulates tumor and mast cell function during human carcinogenesis. Am J Pathol 2006;168:280-291.

24. Guidolin D, Albertin G, Spinazzi R, Sorato E, Mascarin A, Cavallo D, Antonello M, Ribatti D. Adrenomedullin stimulates angiogenic response in cultured human vascular endothelial cells: Involvement of the vascular endothelial growth factor receptor 2. Peptides 2008;29:2013-2023.

25. Levine L, Licci JA 3rd, Pazdrak B, Cheng JZ, Guo YS, Townsend CM Jr, Hellmich MR. Bombesin stimulates nuclear factor kappa B activation and expression of proangiogenic factors in prostate cancer cells. Cancer Res 2003;63:3495-3502.

26. Martínez A, Zudaire E, Julián M, Moody TW, Cuttitta F. Gastrin-releasing peptide (GRP) induces angiogenesis and the specific GRP blocker 77427 inhibits tumor growth in vitro and in vivo. Oncogene 2005;24:4106-4113.

27. Cuttitta F. Peptide amidation: Signature of bioactivity. Anat Rec 1993;236:87-93.

28. Cuttitta F, Treston A, Siegfried J, Quinn K, Avis I, Scott F, Mulshine J. Peptide physiology of human cancer cells and its relationship with autocrine/paracrine growth. In: Polak JM, ed. Diagnostic Histopathology of Neuroendocrine Tumors. London, Churchill Livingstone; 1993:15-39.

29. Cuttitta F, Miller MJ, Montuenga LM, Garayoa M, Elsasser T, Walsh T, Unsworth E, Martínez A. Adrenomedullin: Terra incognita. In: Martinez A, Cuttitta F, eds. Adrenomedullin. Washington, DC: IOS Press; 1998:1-21.

30. Cuttitta F, Carney DN, Mulshine J, Moody TM, Fedorko J, Fischler A, Minna JD. Bombesin-like peptides can function as autocrine growth factors in human small- cell lung cancer. Nature 1985;316:823-826.

31. Miller MJ, Martínez A, Unsworth EJ, Thiele CJ, Moody TW, Elsasser T, Cuttitta F. Adrenomedullin expression is human tumor cell lines. Its potential role as an autocrine growth factor. J Biol Chem 1996;271:23345-23351.

32. Fritz-Six KL, Dunworth WP, Li M, Caron KM. Adrenomedullin signaling is necessary for murine lymphatic vascular development. J Clin Invest 2008;118:40-50. 
33. Jin DH, Harada K, Ohnishi S, Yamahara K, Kangawa K, Nagaya N. Adrenomedullin induces lymphangiogenesis and ameliorates secondary lymphoedema. Cardiovasc Res 2008;80:339-345.

34. Foy WL, Allen JM, McKillop JM, Goldsmith JP, Johnston CF, Buchanan KD. Substance $\mathrm{P}$ and gastrin releasing peptide in bovine mesenteric lymphatic vessels: chemical characterization and action. Peptides 1989;10:533-537.

35. Martinez A, Julián M, Bregonzio C, Notari L, Moody TW, Cuttitta F. Identification of vasoactive nonpeptidic positive and negative modulators of adrenomedullin using a neutralizing antibody-based screening strategy. Endocrinology 2004;145:3858-3865.

36. Mattson MP. Hormesis defined. Ageing Res Rev 2008;7: $1-7$.

37. Ilondo MM, Damholt AB, Cunningham BA, Wells JA, De Meyts $P$, Shymko RM. Receptor dimerization determines the effects of growth hormone in primary rat adipocytes and cultured human IM-9 lymphocytes. Endocrinology 1994;134: 2397-2403.

38. Sterin-Borda L, Furlan C, Orman B, Borda E. Differential regulation on human skin fibroblast by $\alpha 1$ adrenergic receptor subtypes. Biochem Pharmacol 2007;74:1401-1412.

39. Kuwasako K, Cao YN, Nagoshi Y, Kitamura K, Eto T. Adrenomedullin receptors: pharmacological features and possible pathophysiological roles. Peptides 2004;25:2003-2012.

40. Jensen RT, Battey JF, Spindel ER, Benya RV. International Union of Pharmacology. LXVIII. Mammalian Bombesin receptors: Nomenclature, distribution, pharmacology, signaling and function in normal and disease states. Pharmacol Rev 2008;60:1-42.

41. Martínez A, Oh H-R, Unsworth EJ, Bregonzio C, Saavedra JM, Stetler-Stevenson W, Cuttitta F. Matrix metalloproteinase-2 cleavage of adrenomedullin produces a vasoconstrictor out of a vasodilator. Biochem J 2004;383:413-418.
42. Lui VW, Thomas SM, Zhang Q, Wentzel AL, Siegfried JM, Li JY, Grandis JR. Mitogenic effects of gastrin-releasing peptide in head and neck squamous cancer cells are mediated by activation of the epidermal growth factor receptor. Oncogene 2003;22:6183-6193.

43. Zudaire E, Martínez A, Cuttitta F. Adrenomedullin and cancer. Regul Pept 2003;112:175-183.

44. Matsuura M, Onimaru M, Yonemitsu Y, Suzuki H, Nakano T, Ishibashi H, Shirasuna K, Sueishi K. Autocrine loop between vascular endothelial growth factor (VEGF)-C and VEGF Receptor-3 positively regulates tumor-associated lymphangiogenesis in oral squamoid cancer cells. Am J Pathol 2009;175:1709-1721.

45. Chen L. Ocular lymphatics: State-of-the-art review. Lymphology 2009;42:66-76.

46. Skobe M, Dana R. Blocking the path of lymphatic vessels. Nature Med 2009;15:993-994.

47. Albuquerque RJ, Hayashi T, Cho WG, Kleinman ME, Dridi S, Takeda A, Baffi JZ, Yamada K, Kaneko H, Green MG, Chappell J, Wilting J, Weich HA, Yamagami S, Amano S, Mizuki N, Alexander JS, Peterson ML, Brekken RA, Hirashima M, Capoor S, Usui T, Ambati BK, Ambati J. Alternatively spliced vascular endothelial growth factor receptor-2 is an essential endogenous inhibitor of lymphatic vessel growth. Nat Med 2009;15:1023-1030.

Address correspondence to:

Dr. Frank Cuttitta

NCI Angiogenesis Core Facility

Advanced Technology Center

8717 Grovemont Circle, Room 115C

Bethesda, MD 20892-4605

E-mail: cuttittf@mail.nih.gov 